\title{
Correction: Twin deficit hypothesis and reverse causality: a case study of China
}

Umer Jeelanie Banday ${ }^{1 \star} \&$ Ranjan Aneja ${ }^{1}$

Correction to: Palgrave Communications https://doi.org/10.1057/s41599-019-0304-z, published online 20 August 2019.

The original version of this Article contained incorrect text in the main article body.

The following sentences contained errors:

'The structural shift can be seen from the financial side, which affects Chinese saving and investments. The investments got reduced to $40 \%$ and household savings has reduced from $50 \%$ to $40 \%$ of GDP. The cyclic forces can been seen from the trade prospective: the increasing prices of Chinese imports like oil and semiconductors, pulls the current account balance downwards. One the hand the structural shift can be seen from the financial side, which affects Chinese saving and investments. The investments got reduced to $40 \%$ and household savings has reduced from $50 \%$ to $40 \%$ of GDP.'

These sentences have now corrected in both the main article and PDF version and now read as:

'The cyclic forces can be seen from the trade prospective: the increasing prices of Chinese imports like oil and semiconductors, pulls the current account balance downwards. However, the structural shift can be seen from the financial side, which affects Chinese saving and investments. The investments got reduced to $40 \%$ and household savings has reduced from $50 \%$ to $40 \%$ of GDP.'

Published online: 01 October 2019

\footnotetext{
(c) (i) Open Access This article is licensed under a Creative Commons Attribution 4.0 International License, which permits use, sharing, adaptation, distribution and reproduction in any medium or format, as long as you give appropriate credit to the original author(s) and the source, provide a link to the Creative Commons license, and indicate if changes were made. The images or other third party material in this article are included in the article's Creative Commons license, unless indicated otherwise in a credit line to the material. If material is not included in the article's Creative Commons license and your intended use is not permitted by statutory regulation or exceeds the permitted use, you will need to obtain permission directly from the copyright holder. To view a copy of this license, visit http://creativecommons.org/licenses/by/4.0/.
}

(c) The Author(s) 2019

\footnotetext{
${ }^{1}$ Central University of Haryana, Haryana, India. *email: ubanday@gmail.com
} 